\title{
The reproduction cycle of the sea cucumber Holothuria (Holothuria) tubulosa Gmelin, I79 I (Echinodermata Holo- thuroidea Holothuriidae) in Oran coast, Algeria
}

\author{
Yamina Tahri*, Saliha Dermeche, Fayçal Chahrour \& Mohammed Bouderbala
}

\begin{abstract}
Laboratoire Réseau de Surveillance Environnementale (L.R.S.E), Département de Biologie, Faculté des Sciences de la Nature et de la Vie, Université d'Oran 1 Ahmed Ben Bella Oran, 31000 Algeria; e-mail: salydermeche@gmail.com, fayalchahrour@gmail.com,mohammedbouderbala2016@gmail.com

"Corresponding author, e-mail: tahriamina76@gmail.com
\end{abstract}

ABSTRACT The aim of this paper is to present an analytical study of gonad index (GI) and repletion index (RI) of Holothuria (Holothuria) tubulosa Gmelin, 1791 (Echinodermata Holothuroidea Holothuriidae). The study is based on biomonitoring data collected from February 2014 to January 2015 in the Oran coast. The gonad index of Holothuria tubulosa is analyzed to show the reproductive cycle and its relationship to environmental parameter conditions. Samples of 15 to 20 individuals were collected monthly at three stations on the Oran coast (La Madrague, Cap Carbon, and Ain Franin). The sex ratio of all sampling was found as (female: male) 0.8:1.2 with no significant difference between sites $\left(X_{2}=2.18 ; \mathrm{df}=4 ; \mathrm{p}>0.05\right)$ and is also not significant regarding the seasons (spring, summer, autumn, winter) $(\mathrm{X} 2=3.03 ; \mathrm{df}=6$ $; \mathrm{p}>0.05$ ). Sea cucumber reproduction occurred in September at Cap Carbon and Ain Franin with values of Gonad index (GI) that are $0.33 \pm 0.52 \%$ and $0.22 \pm 0.52 \%$ respectively. At the La Madrague site, the spawning occurred in October with a value of GI of $1.49 \pm 2.03 \%$. It was observed that seawater temperature has a positive correlation with Gonad index (GI) and no correlation with Repletion index (RI).

KEYWORDS Gonad index; Holothuria tubulosa; Oran coast; sex ratio; seawater temperature.

Received 07.02.2019; accepted 31.05.2019; published online 30.06.2019

\section{INTRODUCTION}

The aspidochirote Holothuria (Holothuria) tubulosa (Gmelin, 1788) (Echinodermata Holothuroidea Holothuriidae) is widely distributed in the Mediterranean Sea (Francour, 1990; Coulon \& Jangoux, 1993a; Koukouras et al., 2007) where it is an important part of the macrozoobenthos (Mezali et al., 2006; Costa et al., 2014). It lives on rocky substrata, loose sediments, and in sea grass meadows at depths varying between 5 and 100 meters (Ocaña $\&$ Tocino, 2005). Holothuria tubulosa is a common species on the Algerian seabed (Mezali, 2008). It is an ecologically important species because of its role in the recycling of organic matter in Posidonia oceanica (L.) Delile meadows (Costa et al., 2014) and its stabilization of the bacterial community in the sediments (Amon \& Herndl, 1991).

Holothurians have lost pentamerism in their reproductive system (Navarro et al., 2012) and have a single gonad composed of one or two tufts of tubules (Conand, 1989). The gametes are released into the water through gonopore located at the dorsal mesentery (Pérez-Ruzafa, 1984; Conand, 1989). 
The gonads tend to fill most of the interior cavity of the body at their peak maturity stage (PérezRuzafa, 1984). In general, holothurians have a seasonal reproductive cycle (Smiley et al., 1991). However, whilst temperate species generally have spawning periods in spring and summer (Cameron \& Fankboner, 1986; McEuen \& Chia, 1991; Hamel et al., 1993), tropical species may spawn throughout the year (Pearse, 1968; Conand, 1993a; González et al., 2004).

A number of environmental factors may stimulate gonad growth, maturation, and spawning (Fenaux, 1980). For example, sea temperature is an important factor that influences spawning (Fuji, 1960 ) and the inhibition or slowing down of nutrition (Smith, 1971).

In Algeria, there are few studies on sea cucumbers and their spawning. In this study, we will follow the gonad index and repletion index (reproduction and trophic activity) and the influence of environmental factors on the spawning of the H. tubulosa population sampled at three sites on the west coast of Algeria with different locations and substrates.

\section{MATERIAL AND METHODS}

\section{Study area}

The study was conducted on the Oran coast, in the northwest of Algeria. Three sites were selected. Station 1, La Madrague, $35^{\circ} 46^{\prime} 00.58^{\prime \prime} \mathrm{N}-0^{\circ}$ 49 '33.00" W is located on the west of Cape Falcon, and is a rocky site forming a large bay open to the east. Upstream of this coastal site there are farms that are part of the National Plan of Agricultural Development (PNDA). These farms may affect the coastal marine ecosystem through the use of pesticides, fertilizers and phytosanitary products (Benghali et al., 2006). Station 2, Ain Franin, $00^{\circ} 35^{\prime} 46^{\prime} 854^{\prime \prime} \mathrm{N}-30^{\circ} 768^{\prime} 00^{\prime \prime} \mathrm{W}$ is located between two headlands forming the large bay of Oran, Cape Ferrat to the north and Cape Falcon to the southeast and $8 \mathrm{~km}$ far from Kristel. This station is considered as a low-impact anthropogenic area, but there is presence of a source of sulfuric thermal water. Finally, station 3, Cap Carbon, $35^{\circ}$ $54^{\prime} 6.36^{\prime \prime} \mathrm{N}-0^{\circ} 20^{\prime} 20.22^{\prime \prime} \mathrm{W}$ is located near the agglomeration of Arzew. This area is under signif- icant influence of urban and industrial discharges from the presence of a petrochemical industrial complex (Arzew-Ain El Bia, Oran) as shown in figure 1.

\section{Field Sampling}

The study is based on 12 sampling months from February 2014 to January 2015. From 15 to 20 sea cucumbers were collected each month by scuba divers at a depth of up to $10 \mathrm{~m}$, at the three study areas. Temperature, salinity, and $\mathrm{pH}$ of the surface water were measured using a Multiparameter (HANNA-HI9829) instrument. At the laboratory, each animal was dissected along the ventral surface and eviscerated. The gonads and the digestive tract (intestine and digestive contents) were recovered, drained and weighed with electronic scales ( $0.001 \mathrm{~g}$ precision). All gonads were fixed in $10 \%$ formalin for microscopic observations using Microscope: Leica DM 2000. The mean Gonad (GI) and mean Repletion indexes (RI) were calculated using the ratio between the gonad weight or intestine weight (GW, IntW) and the total weight of the gutted body (GBW) by the formula (Asha \& Muthiah, 2008; Gaudron et al., 2008; Kohler et al., 2009).

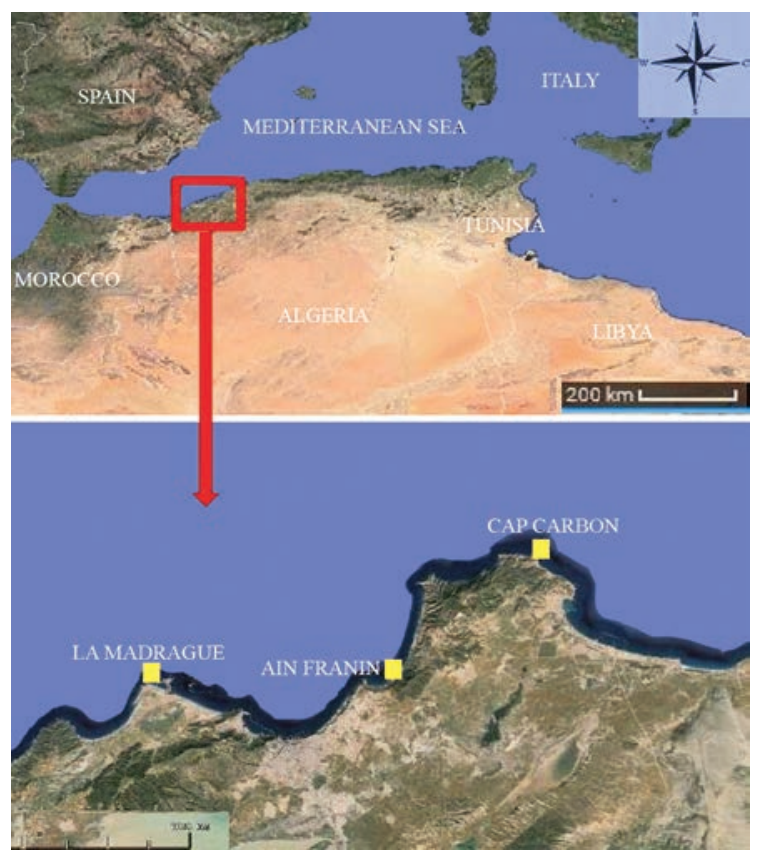

Figure 1. Study area: Oran coast, NW-Algeria. 


$$
\begin{aligned}
& \text { Gonad index }(G I)=\frac{G W}{G B W} \times 100 \\
& \text { Repletion index }(R I)=\frac{\operatorname{lnt} W}{G B W} \times 100
\end{aligned}
$$

\section{Data analysis}

The collected data are computed and analyzed with IBM SPSS 20 software. The sex ratio study was tested by chi-square. The differences in both indexes (GI and RI) between sites, months and seasons were tested through a one-factor ANOVA test and the Tukey test. The relations between GI, RI and environmental factors were determined using the Pearson Correlation Analysis.

\section{RESULTS}

By using the macroscopic and microscopic observations, the gonads of $640 \mathrm{H}$. tubulosa were sexed as 321 females, 259 males, and 60 unidentified individuals. The sex ratio (female:male) is $0.8: 1.2$. The sex ratio at La Madrague (female:male) is 1.25:0.79, at Cap Carbon is 1.2:0.83 and at Ain Franin is $1.27: 0.78$. By chi-square test, the difference in sex ratio compared to sites is not significant $\left(X_{2}=2.18 ; \mathrm{df}=4 ; \mathrm{p}>0.05\right)$ and also not significant compared to the seasons (spring, summer, autumn, winter) $(\mathrm{X} 2=3.03 ; \mathrm{df}=6 ; \mathrm{p}>0.05)($ Table 1$)$.

The study was performed on 640 samples collected during sampling campaign. The collected samples allowed us to determine the changes in the Repletion index (RI) and the Gonad index (GI). The averages of repletion and gonad indexes are characterized by a monthly change which is greater for the repletion index (Table 2).

The monthly average repletion index gives the most variations which were the maximum $76.56 \pm$ $14.13 \%$ in October and the minimum $31.47 \pm$ $20.95 \%$ in September at Cap Carbon. For the Ain Franin site the maximum is $97.67 \pm 21.26 \%$ in March and the minimum is $22.55 \pm 6.22 \%$ in September (Fig. 2). For the La Madrague site, the repletion index is different from the previous sites, the minimum is $20.97 \pm 6.40 \%$ in February and the maximum is $81.77 \pm 13.47 \%$ in October (Fig. 2).

\begin{tabular}{|c|c|c|c|}
\hline & Chi-square $X_{2}$ & $d f$ & $P$ \\
\hline sites & 2.18 & 4 & 0.702 \\
\hline seasons & 3.03 & 6 & 0.805 \\
\hline
\end{tabular}

Table 1. The difference in sex ratio compared to

\begin{tabular}{|c|c|c|c|c|c|c|c|c|c|c|c|c|c|}
\hline \multicolumn{2}{|c|}{ Area } & $\mathrm{Feb}$ & Mar & Apr & May & Jun & Jul & Agu & Sep & Oct & Nov & Dec & Jan \\
\hline \multirow{4}{*}{$M A$} & & 0.94 & 1.26 & 3.58 & 1.69 & 16.27 & 15.86 & 22.85 & 14.52 & 1.49 & 2.18 & 0.23 & 0.2 \\
\hline & GI & $(0.56)$ & $(0.44)$ & (2.15) & (1.11) & (8.32) & $(8.40)$ & (20.71) & $(9.33)$ & (2.03) & (2.09) & $(0.36)$ & $(0.36)$ \\
\hline & & 20.97 & 24.32 & 39.28 & 35.40 & 66.67 & 67.03 & 64.84 & 52.27 & 81.77 & 72.63 & 48.84 & 49.82 \\
\hline & $R I$ & $(6.40)$ & (10.42) & (12.76) & (12.96) & (12.17) & (20.21) & (21.82) & $(9.83)$ & (13.47) & (16.79) & $(25.15)$ & $(24.74)$ \\
\hline \multirow{4}{*}{ C.C } & & 0.53 & 1.61 & 1.16 & 12.57 & 13.92 & 9.31 & 8.79 & 0.33 & 0.73 & 0.81 & 1.86 & 1.24 \\
\hline & $G I$ & $(0.51)$ & (1.22) & $(0.84)$ & $(4.71)$ & $(4.39)$ & $(6.43)$ & $(6.35)$ & $(0.52)$ & $(0.94)$ & $(0.86)$ & (1.79) & (1.16) \\
\hline & & 56.81 & 51.44 & 40.48 & 49.54 & 49.78 & 38.55 & 35.85 & 31.47 & 76.56 & 73.47 & 73.96 & 59.11 \\
\hline & $R I$ & (20.32) & (14.36) & (15.29) & (13.54) & (14.55) & (13.10) & (8.67) & (20.95) & (14.13) & (18.46) & (16.98) & (11.35) \\
\hline \multirow{4}{*}{$A F$} & & 1.05 & 1.54 & 6.30 & 4.69 & 10.75 & 9.82 & 10.61 & 0.22 & 0.39 & 1.47 & 1.5 & 1.55 \\
\hline & $G I$ & (1.33) & (1.3)1 & $(4.40)$ & (3.38) & (3.41) & (5.67) & $(4.30)$ & $(0.52)$ & $(0.55)$ & (2.89) & (1.32) & (1.19) \\
\hline & & 80.47 & 97.67 & 67.17 & 65.33 & 61.46 & 42.12 & 51.63 & 22.55 & 68.59 & 63.31 & 68.55 & 61.26 \\
\hline & $R I$ & (19.66) & (21.26) & $(16.12)$ & 27.69 & (14.36) & (15.24) & (19.27) & $(6.22)$ & (20.60) & (20.65) & $(19.02)$ & (12.77) \\
\hline
\end{tabular}
sites and seasons by Test Chi-square.

Table 2. Monthly mean evolution of physiological index of Holothuria tubulosa in the study area. MAD: La Madrague. CC: Cap Carbon. AF: Ain Franin. Expressed \% (standard deviation). 
It can be noted that the highest average index of repletion is recorded at Ain Franin where the environment is rich in flora and fauna and with the presence of Posidonia oceanica meadows. This site is influenced by sporadic pollution, while the Cap Carbon site is under the influence of industrial pollution (Chahrour et al., 2013). The site of La Madrague presents a stony substrate with some clumps of Posidonia K.D. Koenig and it is under the influence of an agricultural pollution (Benghali et al., 2006).

The monthly variations of average gonad index are summarized in figure 3. For Cap Carbon and Ain Franin sites, respectively, the minimum values of $0.33 \pm 0.52 \%$ and $0.22 \pm 0.52 \%$ were recorded in September, while maximum values of 13.92 $\pm 4.39 \%$ and $10.75 \pm 3.41 \%$ in June. On the other hand, for the La Madrague site, the average gonad index minimum value of $0.2 \pm 0.36 \%$ is registred in January and the maximum value is $22.85 \pm 20.71 \%$ in August.

The maximum values of the gonad index were recorded in June and August, while during the winter season it is slowly decreasing. This decrease in GIm means (see Figs. 2, 3) that the gonad development is in pre-reproduction or spawning (Tanaka, 1958; Spirlet et al., 2000). These declines in GIm denote the existence of an autumn season spawning (September and October), as shown in figure 3.

The statistical study by ANOVA test shows no significant differences between GIm and the three sites $(\mathrm{df}=2 ; \mathrm{F}=0.62 ; \mathrm{P}>0.05)$ in contrast to the monthly and seasonal variation, GI has a significant difference $(\mathrm{df}=11 ; \mathrm{F}=5.02 ; \mathrm{P}<0.05)(\mathrm{df}=3 ; \mathrm{F}=18.59$;

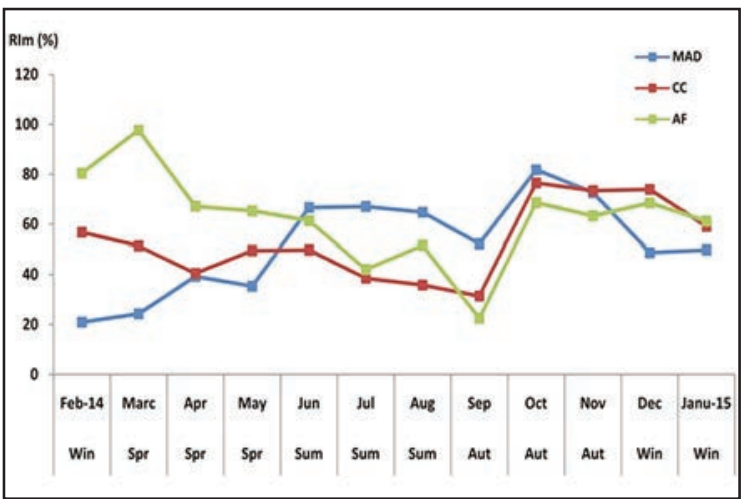

Figure 2. Monthly mean evolution of repletion index Holothuria tubulosa in the area. MAD: La Madrague. CC: Ca Carbon. AF: Ain Franin.
$\mathrm{P}<0.05)$. Whereas for the RI, the difference is insignificant compared to sites, months and seasons. In this study, the microscopic observations confirm the spawning period of the population at the three sites. The tubules of the females and the males almost resorbed especially in the cold months as has been observed by Conand (1993a). In the hot months the gonads are more mature and prepare to spawn. This behavior was also reported by Navarro et al. (2012).

The females and males gonads are composed of 4 stages of maturity in the whole of the year.

Figures 4-9 shows the microscopic and macroscopic observations of female gonads of $\mathrm{H}$. tubulosa. Stage I (recovery stage), in this case, it was not observed.

Stage II. Growing (Figs. 4, 5): tubule with earlyvitellogenic oocytes and thick tubule walls.

Stage III. Mature (Fig. 6): tubule with mid-vitellognic oocytes.

Stage IV. Partly spawned (Figs. 7, 8): tubule with vitellogenic mature oocytes. The mature oocytes with a nucleus, germinal vesicle and follicular epithelium.

Stage V. Spent (Fig. 9): spawned tubule with the presence of relict oocytes and with pointed tubule end.

The microscopic observations of male gonads of $H$ tubulosa are depicted in figures 10-15. Stage I (recovery stage), in this case, it was not observed.

Stage II. Growing (Figs. 10, 11): thick tubule with spermatozoa and growing tubule longitudinal fold.

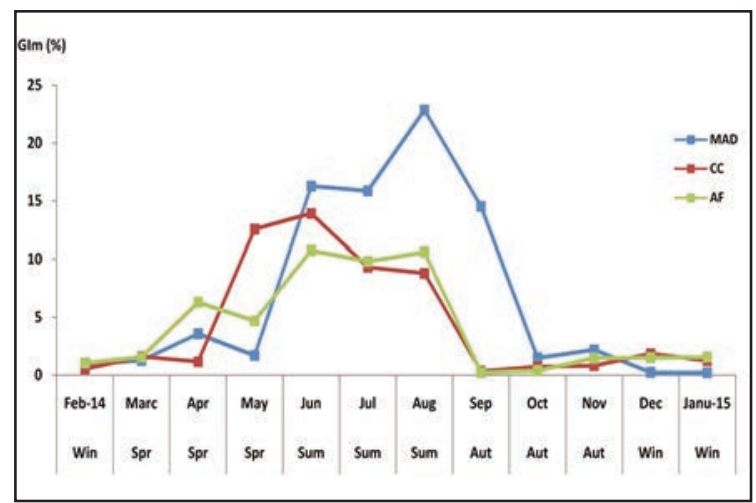

Figure 3. Monthly mean evolution of gonad index of Holothuria tubulosa in the area. MAD: La Madrague. CC: Cap Carbon. AF: Ain Franin. 


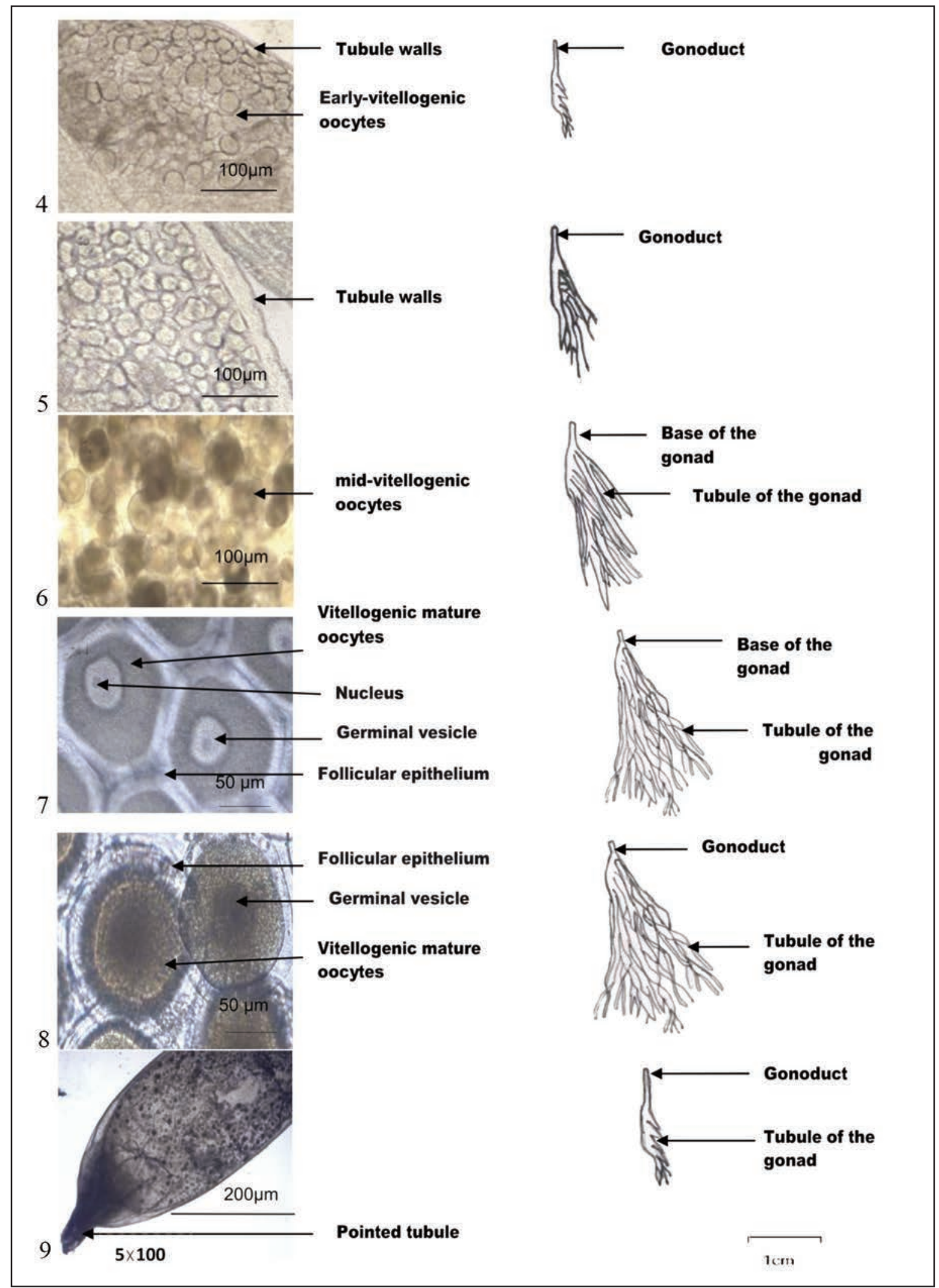

Figures 4-9. Microscopic and macroscopic observations of female gonads of Holothuria tubulosa. 


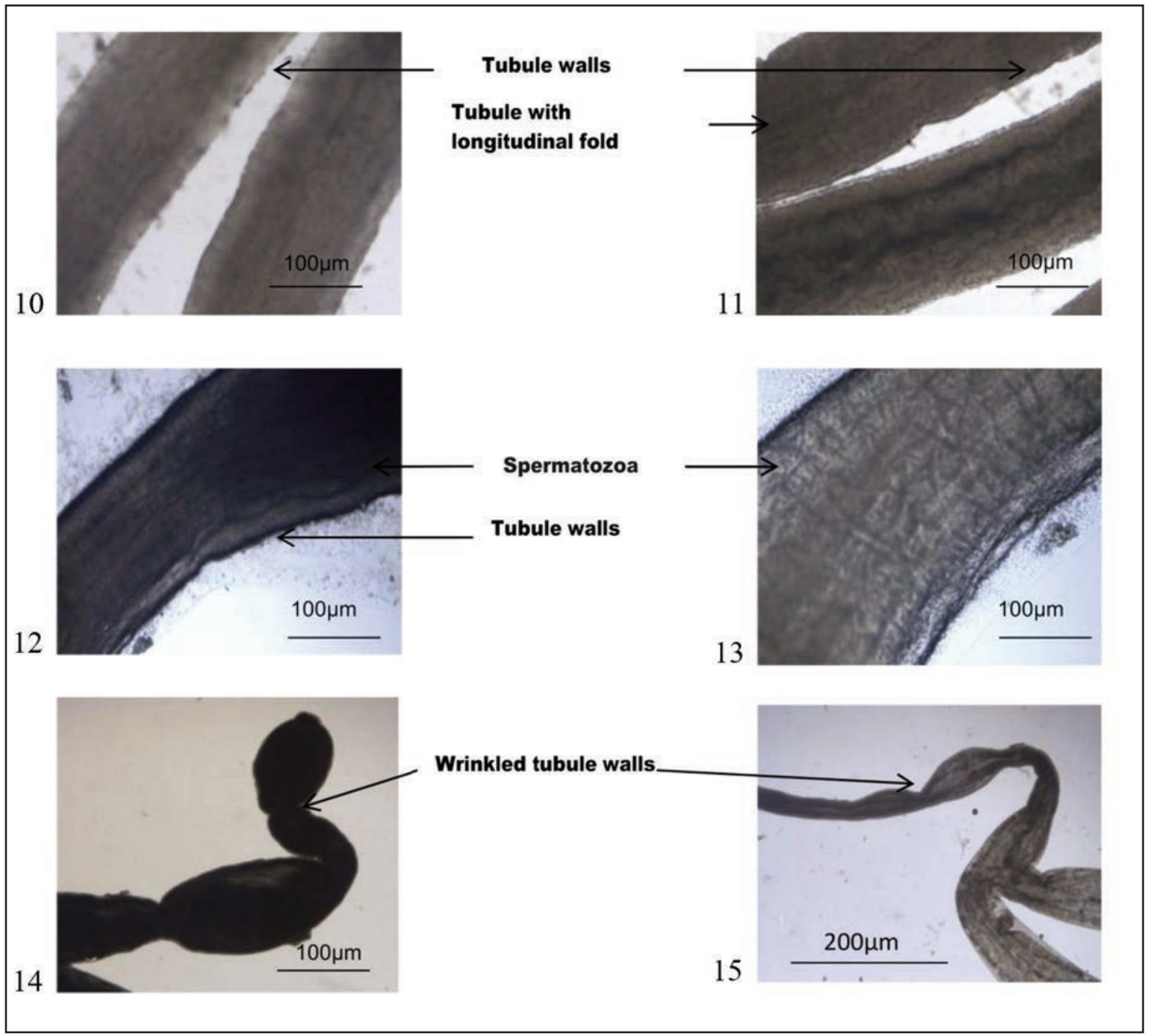

Figures 10-15. Microscopic observations of male gonads of Holothuria tubulosa.

Stage III. Mature (Figs. 12, 13): tubule with complete spermatozoa.

Stage IV. Partly spawned (Fig. 14): tubule with wrinkled and partly spawned.

Stage V. Spent (Fig. 15): tubule with wrinkled wall and completely spent.

Figures 16-24 show the effect of environmental conditions on gonad index and repletion index, where it can be seen that the temperature is the most important factor in the reproduction and feeding. For the three sites, the spawning period is between September and October where the temperature is around $19-20{ }^{\circ} \mathrm{C}$. For the repletion index, the highest means are in the autumn season for two sites (La Madrague and Cap Carbon). For Ain Franin, on the other hand, it is during the spring season.

According to Spirlet et al. (2000) and Shpigel et al. (2004), an increase in temperature may increase ingestion and absorption efficiency and stimulate the growth and biological activities of sea cucumbers. In the autumn season, H. hawaiiensis Fisher, 1907 ingests more sediments than during the rest of the year to allow the growth of his sexual organs and the expulsion of gametes (Dar \& Ahmad, 2006). Also the previous results confirm that the temperature is the most important factor affecting 
the reproduction of $H$. tubulosa (Navarro et al., 2012; Dereli et al., 2016; Bahiri et al., 2017).

The average physical seawater parameters of the three sampling sites in Oran coast are summarized in Table 3.

There is no significant difference between the stations, the temperature, and $\mathrm{pH}$. However, there is a significant difference between salinity and the study sites.

The temperature has a positive relationship with gonad index $(\mathrm{p}<0.01)$ as shown by the Pearson correlation analysis, presented in Table 4 , and no correlation between temperature and index repletion. The $\mathrm{pH}$ has a positive correlation with gonad index $(p<0.05)$ and also has a positive relationship with the temperature $(\mathrm{p}<0.01)$.

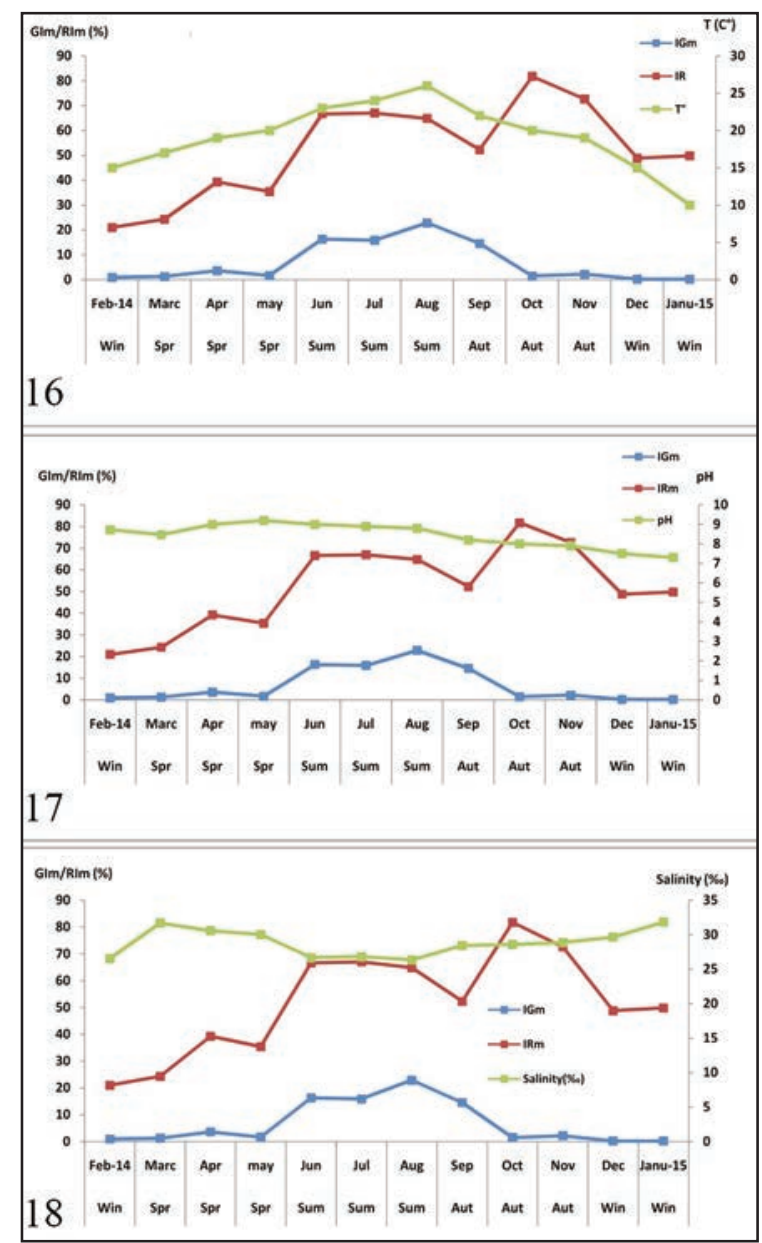

Figures $16-18$. Monthly mean gonad index and repletion index of Holothuria tubulosa at La Madrague. Mean seawater temperature (Fig. 16), pH (Fig. 17) and salinity (Fig. 18).

\section{DISCUSSION}

The sex ratio obtained from $H$. tubulosa in this study shows a significant difference in the relationship 1:1. In most sea cucumbers of the Aspidochirotida order the sex ratio usually coincides with a balanced relationship 1:1 (Ramofafia et al., 2001; Rasolofonirina et al., 2005; Asha \& Muthiah, 2008). Despite some species show a slightly unbalanced ratio, with more males than females, or vice versa (McPherson, 1965; Navarro et al., 2012), some sea cucumber species have an unbalanced ratio of $1: 2$ or $2: 3$ due to fishing pressure affecting the population (Shiell \& Uthicke, 2006; Muthiga et al., 2009). In Algeria, sea cucumbers are not exploited, thus it is assumed that

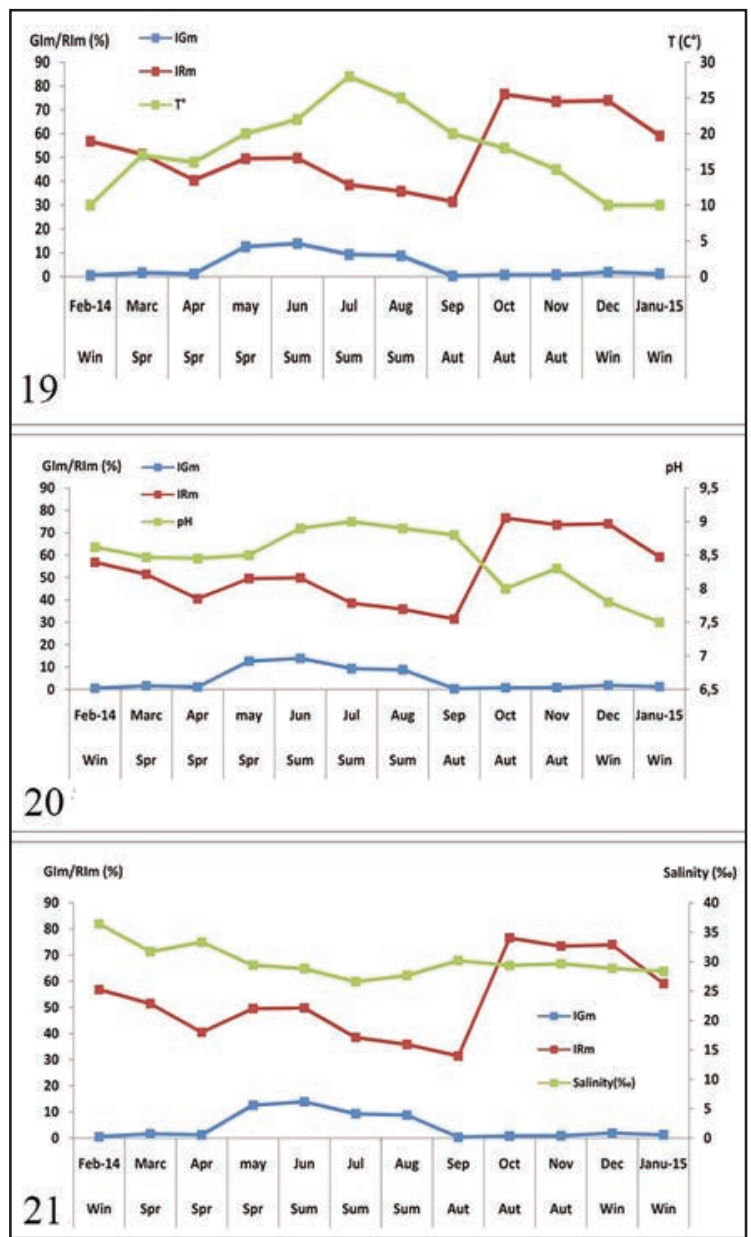

Figures 19-21. Monthly mean gonad index and repletion index of Holothuria tubulosa at Cap Carbon. Mean seawater temperature (Fig. 19), pH (Fig. 20) and salinity (Fig. 21). 
there is another important factor that affects the balance of the sex ratio. This sex ratio unbalance can be explained by the pollution or the hydrodynamics which often favors the reduction of the populations as a response to stress.

In a population of $H$. tubulosa, the determination of the fluctuations of the digestive contents weight and the gonads is an essential approach to the trophic and spawning study of this marine invertebrate. It allows, primarily, to determine the structure and the evolution of benthic phytocenosis (Nedelec, 1982; Verlaque \& Nedelec, 1983a, b) and secondly to clarify the gonadal activity.

The average repletion index shows maximum values in October and March and minimum values in September and February. Dar \& Ahmad (2006)

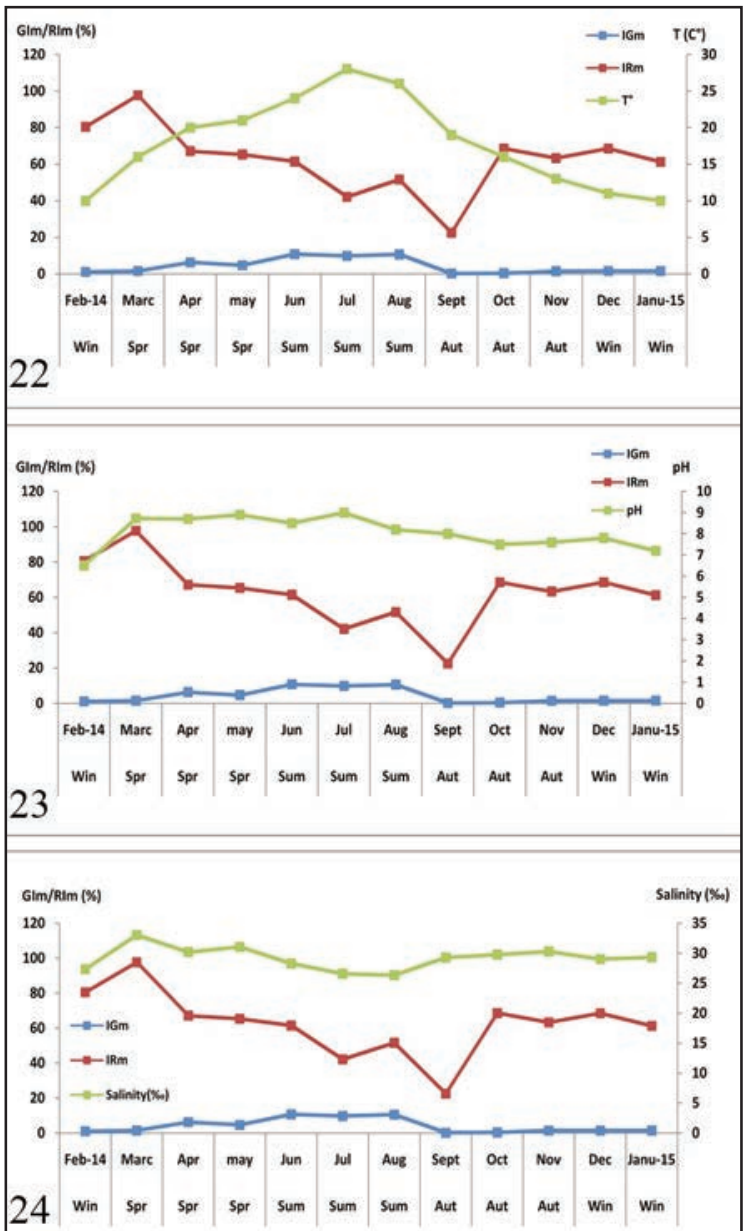

Figures 22-24. Monthly mean gonad index and repletion index of Holothuria tubulosa at Ain Franin. Mean seawater temperature (Fig. 22), pH (Fig. 23) and salinity (Fig. 24). observed that $H$. atra Jaeger, 1833 in the Red Sea has the highest average weight and the lowest average percentage of sediments in spring. They concluded that at this time of the year the most individuals are at the stag, which precedes the maturation and are preparing for the period of reproduction, from June to July. They also observed (Dar \& Ahmad, 2006) that the highest mean sediment weights were recorded in summer when individuals need sediments to contract and expel their gametes.

Feeding behavior and feeding mechanism of sea cucumbers during the different seasons are related to the stage of sexual maturation of the animal (Dar $\&$ Ahmad, 2006). The sea cucumbers often show an annual cycle of reproduction as observed by other studies (Navarro et al., 2012; Mezali et al., 2014; Dereli et al., 2016).

The study shows that GIm values increased during the year, and the spawning peak is registered when the GI values are low in October for the $\mathrm{La}$ Madrague site and in September for the other two sites (Ain Franin and Cap Carbon), while GI values have their maximum between June and August. The field observations show and confirm that spawning occurs in shallow waters during the summer in the Mediterranean populations (Valls, 2004; Moosleitner, 2006; Andrade et al., 2008). The results of our study coincide with those of the work performed in the regions of the Dardanelles Strait (Dereli et al., 2016) and of the Aegean Sea (Kazanidis et al., 2010; Kazanidis et al., 2014) and other regions (Despalatović et al., 2004; Navarro et al., 2012) (see Table 5 with $H$. forskali Delle Chiaje, 1823 and $H$. sanctori Delle Chiaje, 1824 ).

For many species of echinoderms, the spawning is extended over a long period, but the reproduction season can be shortened when the environmental conditions are not favorable for a short period (Giese, 1987; Chia \& Walker, 1991; Pearse \& Cameron, 1991).

The correlation was observed between GIm of Holothuria tubulosa and the sea water temperature of the Oran coast. This result confirms previous studies that claim that the temperature is the most important factor affecting reproduction of $\mathrm{H}$. tubulosa (Despalatović et al., 2004; Kazanidis et al., 2010) and other congeneric species (Conand, 1981; Tuwo \& Conand, 1992; Despalatović et al., 2003).

The seasonal variations of seawater temperature and photoperiod are common parameters correlated 


\begin{tabular}{|l|c|c|c|}
\hline Area & $\mathrm{T}^{\circ}(\mathrm{C})$ & $\mathrm{pH}$ & Salinity $(\%)^{\circ}$ \\
\hline La Madrague & $19.16 \pm 4.26$ & $8.42 \pm 0.66$ & $28.85 \pm 1.89^{\mathrm{a}}$ \\
\hline Cap Carbon & $17.58 \pm 5.85$ & $8.44 \pm 0.45$ & $30.03 \pm 2.56^{\mathrm{b}}$ \\
\hline Ain Franin & $17.83 \pm 5.94$ & $8.05 \pm 0.73$ & $29.22 \pm 1.83^{\mathrm{a}}$ \\
\hline
\end{tabular}

Table 3. The comparison of physical parameters at stations in Oran coast (mean \pm standard deviation). *: Significant difference between salinity and sites (Madrague and Cap Carbon. $\mathrm{p}<0.05$; Cap Carbon and Ain Franin. $\mathrm{p}<0.05$ ).

with reproductive synchrony (Boolootian, 1966; Giese \& Pearse, 1974). Although, some echinoderms appear to show more prolonged or continuous spawning throughout the year in tropical climate regions (Harriott, 1985).

In literature, some studies show the existence of a close relationship between temperature and reproduction of Actinopyga mauritiana (Quoy \& Gaimard, 1834) in the island of Guam (Conand \& Sloan, 1989; Conand, 1993a, b). In fact, in the Mediterranean Sea, another study suggests that the spawning would be induced when the water temperature is between $13-20{ }^{\circ} \mathrm{C}$ (Fenaux, 1980). In our study, it is clear that the beginning of spawning depends on the sea temperature in the populations of the three sites (Figs. 4a, 5a, 6a). The starting point of the spawning of this echinoderm is much more induced by the sudden increase of sea temperature due to salinity and $\mathrm{pH}$. There are other factors favoring the induction gametic, such as turbulence (Pedrotti, 1993; Soualili, 2008), the phytoplankton blooms (Pedrotti, 1993; Starr et al., 1993), the hydrodynamics (Soualili, 2008; Dermeche, 2010; Navarro et al., 2012) and the photoperiod (Starr et al., 1993; Spirlet et al., 1998).

The effect of sea temperature and light variations on sea cucumber feeding activity is not extensively documented in the literature. Coulon \& Jangoux (1993b) estimated that a sea cucumber population can filter from 6 to $13 \mathrm{~kg}$ of sediments according to temperature and body size. Due to this activity, the sea cucumbers alter the stability of the seabed (Massin, 1982; Coulon \& Jangoux, 1993b; Dar \& Ahmad, 2006).

\section{CONCLUSIONS}

In this study, it has been able to estimate and evaluate the spawning period of $H$. tubulosa. The sex ratio was found as (female: male) 0.8:1.2 with no significative difference between sites and seasons (spring, summer, autumn, winter). The spawning period was between September and October in the west coast of Oran. The peak spawning is reg-

\begin{tabular}{|c|c|c|c|c|c|c|c|}
\hline & $\mathrm{T}^{\circ}(\mathrm{C})$ & $\mathrm{pH}$ & Salinity (\%) & $\mathrm{GI}$ & $\mathrm{RI}$ & station & Months \\
\hline $\mathrm{pH}$ & $0.569^{* *}$ & & & & & & \\
\hline Salinity (\%) & 0.015 & 0.176 & & & & & \\
\hline GI & $0.712^{* *}$ & $0.370^{*}$ & -0.131 & & & & \\
\hline RI & -0.232 & -0.242 & -0.220 & 0.018 & & & \\
\hline Station & -0.101 & -0.194 & 0.027 & -0.173 & 0.243 & & \\
\hline Months & -0.224 & $-0.339^{*}$ & -0.148 & -0.137 & 0.206 & 0.000 & \\
\hline Seasons & $0.563^{* *}$ & 0.195 & 0.057 & 0.246 & 0.053 & 0.000 & 0.194 \\
\hline
\end{tabular}

Table 4. Correlation between physical parameters of areas, physiological index (GI, RI), months and seasons. $*$ : significantly different $(\mathrm{p}<0.05)$. $* *$ : significantly different $(\mathrm{p}<0.01)$. 
istered where the values of GI are low in October for the La Madrague site with values of $1.49 \pm 2.03$ $\%$, and in September for the other two sites of Cap Carbon and Ain Franin, with values of $0.33 \pm 0.52$ $\%$ and $0.22 \pm 0.52 \%$ respectively, while the GI values have their maximum between June and August.
The temperature of seawater seems to play a crucial role in the release of gametes.

Other studies are also needed on this coast and generally in all the Algerian coasts in order to obtain more information (density, mortality, and longevity).

\begin{tabular}{|c|c|c|c|c|c|}
\hline Species & Location & Methods & $\begin{array}{l}\text { Reproductive } \\
\text { pattern }\end{array}$ & $\begin{array}{l}\text { Spawning } \\
\text { period }\end{array}$ & Reference \\
\hline H. tubulosa & Oran coast, Algeria & GI & Annual & Sept-Oct & Ower study \\
\hline H. tubulosa & Oran coast, Algeria & GI & Annual & $\begin{array}{l}\text { Mar- Apr- } \\
\text { Jul and Oct }\end{array}$ & $\begin{array}{l}\text { Bahiri et al., } \\
2017\end{array}$ \\
\hline H. tubulosa & $\begin{array}{c}\text { Dardanelles Strait, } \\
\text { Turkey }\end{array}$ & GI & Annual & $\begin{array}{l}\text { August and } \\
\text { September }\end{array}$ & $\begin{array}{l}\text { Derlie et al., } \\
2016\end{array}$ \\
\hline H. tubulosa & $\begin{array}{c}\text { Pagasitikos Gulf, } \\
\text { western Aegean Sea, } \\
\text { Greece }\end{array}$ & $\begin{array}{l}\text { Histological } \\
\text { examination }\end{array}$ & Annual & Summer & $\begin{array}{l}\text { Kaznidis et al., } \\
2014\end{array}$ \\
\hline H. tubulosa & Adriatic Sea, Croatia & $\begin{array}{l}\text { Histological } \\
\text { examination }\end{array}$ & Annual & Jul- sept & $\begin{array}{l}\text { Despalatovic et } \\
\text { al., } 2004\end{array}$ \\
\hline H. tubulosa & $\begin{array}{l}\text { Costa Brava,the north } \\
\text { east coast of Spain }\end{array}$ & $\begin{array}{l}\text { Field spawning } \\
\text { observation }\end{array}$ & & $\begin{array}{l}\text { June and } \\
\text { July }\end{array}$ & Valls, 2004 \\
\hline H. tubulosa & Ischia Island, Italy & $\begin{array}{l}\text { Field spawning } \\
\text { observation }\end{array}$ & Annual & August-sept & $\begin{array}{l}\text { Bulteel et al., } \\
1992\end{array}$ \\
\hline H. forskali & Britain & $\begin{array}{l}\text { Histological } \\
\text { examination and } \\
\text { GI }\end{array}$ & Annual & Apr- June & $\begin{array}{c}\text { Tuow \& Conand, } \\
1992\end{array}$ \\
\hline H. forskali & Adriatic Sea & $\begin{array}{l}\text { Histological } \\
\text { examination }\end{array}$ & Annual & $\begin{array}{l}\text { Jun-August } \\
\text { and Dec }\end{array}$ & $\begin{array}{l}\text { Despalatovic et } \\
\text { al., } 2003\end{array}$ \\
\hline H. sanctori & Gran Canaria, Spain & $\begin{array}{l}\text { GI, macro and } \\
\text { microscopic } \\
\text { analysis of the } \\
\text { physical } \\
\text { characteristics of } \\
\text { tubules. }\end{array}$ & annual & Jun-August & $\begin{array}{l}\text { Navarro et al., } \\
2012\end{array}$ \\
\hline
\end{tabular}

Table 5. Characteristics of Holothurian species reproduction. Location, methods used and spawning period. 


\section{REFERENCES}

Amon R.M. \& Herndl G.J., 1991. Deposit feeding and sediment. Marine Ecology, 12: 163-174. https://doi. org/10.1111/j.1439-0485.1991.tb00250.x

Andrade Á.A., Machado L.F., Barreiros J.P., Paulay G. $\&$ Cardigos F., 2008. In situ observation of sexual reproduction of Holothuria tubulosa Gmelin 1788 (Echinodermata: Holothuroidea) in the Azores (NE Atlantic). La bêche-de-mer, Bulletin d'information de la CPS, 27: 43-45.

Asha P. \& Muthiah P., 2008. Reproductive biology of the commercial sea cucumber Holothuria spinifera (Echinodermata: Holothuroidea) from Tuticorin. Tamil Nadu. India. Aquaculture International, 16: 231-242. https://doi.org/10.1007/s10499-007-9140$\mathrm{Z}$

Bahiri D., Dermeche S., Chahrour F., Tahri Y. \& Bouderbala M., 2017. Study of the Physiological Indices of Sea Cucumber Holothuria tubulosa (Gmelin. 1788) of the Oranaise Coast (Algeria). International Journal of Sciences, Basic and Applied Research (IJSBAR) 36: 1-17.

Benghali S., Taleb M. \& Boutiba Z., 2006. Biosurveillance de la pollution marine au niveau de la côte occidentale algérienne par la mesure de l'activité de l'acétylcholinestérase chez l'oursin Paracentrotus lividus et la patelle Patella coerulea. Mémoire de Magister.

Birkeland C., 1988. Geographic comparisons of coralreef community processes. Proceedings of the Sixth International Coral Reef Symposium, pp. 211-220.

Boolootian R.A., 1966. Reproductive physiology. In: Boolootian R.A. (Ed.), Physiology of the Echinodermata, pp. 561-613. New York: John Wiley \& Sons.

Boudouresque C.F. \& Meinesz A., 1982. Découverte de l'herbier de Posidonie. Cahiers Parc National PortCros, France, 4: 1-79.

Cameron J.L. \& Fankboner P.V., 1986. Reproductive biology of the commercial sea cucumber Parastichopus californicus (Stimpson) (Echinodermata: Holothuroidea). I. Reproductive periodicity and spawning behavior. Canadian Journal of Zoology, 64: 168-175. https://doi.org/10.1139/z86-027

Chahrour F., Boumaza S., Semroud R. \& Boutiba Z., 2013. Phenology of Posidonia oceanica (Linnaeus) Delile in the West Coast of Algeria. International Journal of Asian Social Science, 3: 240-254.

Chia F.-S. \& Walker C.W., 1991. Echinodermata: Asteroidea. In: Giese A.C., Pearse J.S. \& Pearse V.B. (Eds.), Reproduction of marine invertebrates, echinoderms and lophophorates. Volume VI. pp. 301-340. Boxwood Press, Pacific Groove, California, USA.

Conand C., 1981. Sexual cycle of three commercially important holothurian species (Echinodermata) from the lagoon of New Caledonia. Bulletin of Marine Science, 31: 523-543.

Conand C., 1989. Les holothuries aspidochirotes du lagon de Nouvelle-Calédonie: biologie, écologie et exploitation. ORSTOM, Paris, Etudes et Thèses, 393 pp.

Conand C., 1993a. Reproductive biology of the holothurians from the major communities of the New Caledonian Lagoon. Marine Biology, 116: 439-450. https://doi.org/10.1007/bf00350061

Conand C., 1993b. Ecology and reproductive biology of Stichopus variegatus an Indo-Pacific coral reef sea cucumber (Echinodermata: Holothuroidea). Bulletin of Marine Science, 52: 970-981.

Conand C. \& Sloan N., 1989. World fisheries for echinoderms. In: Caddy J.T. (Ed.), Marine Invertebrate Fisheries: Their assessment and management, pp. 647-663.

Costa V., Mazzola A. \& Vizzini S., 2014. Holothuria tubulosa Gmelin, 1791 (Holothuroidea. Echinodermata) enhances organic matter recycling in Posidonia oceanica meadows. Journal of Experimental Marine Biology and Ecology, 461: 226-232. https://doi. org/10.1016/j.jembe.2014.08.008

Coulon P. \& Jangoux M., 1993a. Feeding rate and sediment reworking by the holothuroid Holothuria tubulosa (Echinodermata) in a Mediterranean seagrass bed. Marine ecology, Progress series, 92: 201204. https://doi.org/10.3354/meps092201

Coulon P. \& Jangoux M., 1993b. Feeding rate and sediment reworking by the holothuroid Holothuria tubulosa (Echinodermata) in a Mediterranean seagrass bed off Ischia Island. Italy. Marine Ecology Progress Series, 92: 201-204. https://doi.org/10.3354/meps 092201

Dar M.A. \& Ahmad H.O., 2006. Le comportement alimentaire sélectif et le rôle écologique des holothuries vivant dans les eaux peu profondes de la Mer Rouge. La bêche-de-mer - Bulletin de la CPS, 24: $11-15$.

Dereli H., Çulha S.T., Culha M., Özalp B. \& Tekinay A., 2016. Reproduction and population structure of the sea cucumber Holothuria tubulosa in the Dardanelles Strait. Turkey. Mediterranean Marine Science, 17: 47-55. https://doi.org/10.12681/mms. 1360

Dermeche S., 2010. Indices physiologiques. Métaux lourds $(\mathrm{Cd}, \mathrm{Pb}, \mathrm{Cu}, \mathrm{Zn}$ et $\mathrm{Ni})$ et bioessais chez l'oursin commun Paracentrotus lividus (Lamarck. 1816) pêché dans le golfe d'Arzew et d'Oran. Thèse Université d'Oran.

Despalatović M., Grubelić I., Antolić B. \& Žuljević A., 2004. Reproductive biology of the holothurian Holothuria tubulosa (Echinodermata) in the Adriatic Sea. Journal of the Marine Biological Association of the United Kingdom, 84: 409-414. 
Despalatović M., Grubelić I., Šimunović A., Antolić B. $\&$ Žuljević A., 2003. New data about reproduction of the holothurian Holothuria forskali (Echinodermata) living in geographically different places. Fresenius environmental bulletin, 12: 1345-1347. https://doi. org/10.1017/s0025315404009361h

Fenaux L., 1980. Cycles saisonniers de reproduction et croissance larvaire chez les Echinodermes. Oceanis, 6: 277-307.

Francour P., 1990. Dynamique de l'écosystème à Posidonia oceanica dans le parc national de Port-Cros: analyse des compartiments matte. Litière, faune vagile. Echinodermes et poissons. Université d'AixMarseille II. Faculté des sciences.

Francour P. \& Le Direach L., 1994. Recrutement de l'ichtyofaune dans l'herbier superficiel à Posidonia oceanica dans la réserve marine de Scandola (Corse. Méditerranée nord-occidentale): données préliminaires. Travaux scientifiques du Parc naturel régional et des Réserves naturelles de Corse, 46: 71-91.

Fuji A., 1960. Studies on the biology of the sea urchin: III. Reproductive Cycle of Two Sea Urchins. Strongylocentrotus nudus and S. intermedius. in Southern Hokkaido. Bulletin of the faculty of fisheries Hokkaido University, 11: 49-57.

Gaudron S., Kohler S. \& Conand C., 2008. Reproduction of the sea cucumber Holothuria leucospilota in the Western Indian Ocean: biological and ecological aspects. Invertebrate Reproduction \& Development, 51: 19-31. https://doi.org/10.1080/07924259.2008.9652 253

Giese A., 1987. Maturation and spawning. Reproduction of marine invertebrates, 9: 251-329.

Giese A.C. \& Pearse J.S., 1974. Introduction: general principles. In: Giese A.C. \& Pearse J.S. (Eds.), Reproduction of marine invertebrates, Vol 1: Acoelomate and Pseudocoelomate metazoans. Academic Press, New York, pp. 1-49.

González R.M., Moguel C.Z., Bolio M.C. \& Canul. R.P., 2004. Concentración de $\mathrm{Cd}$. Cr. Cu y Pb en sedimentos y en tres especies de pepino de mar (clase holothuroidea) de las costas del Estado de Yucatán. México. Ingeniería, 8: 7-19.

Hamel J.F., Himmelman J.H. \& Dufresne L., 1993. Gametogenesis and spawning of the sea cucumber Psolus fabricii (Duben \& Koren). The Biological Bulletin, 184: 125-143. https://doi.org/10.2307/154 2223

Harriott V.J., 1985. Mortality rates of scleractinian corals before and during a mass bleaching event. Marine Ecology Progress Series, 21: 81-88.

Ismail H., Lemriss S., Ben Aoun Z., Mhadhebi L., Dellai A., Kacem Y., Boiron P. \& Bouraoui A., 2008. Antifungal activity of aqueous and methanolic extracts from the Mediterranean sea cucumber Holothuria polii. Journal of Medical Mycology, 18: 23-26. https://doi.org/10.1016/j.mycmed.2008.01.002

Kazanidis G., Antoniadou C., Lolas A.P., Neofitou N., Vafidis D., Chintiroglou C. \& Neofitou C., 2010. Population dynamics and reproduction of Holothuria tubulosa (Holothuroidea: Echinodermata) in the Aegean Sea. Journal of the Marine Biological Association of the United Kingdom, 90: 895-901. https:// doi.org/10.1017/s0025315410000251

Kazanidis G., Lolas A. \& Vafidis D., 2014. Reproductive cycle of the traditionally exploited sea cucumber Holothuria tubulosa (Holothuroidea: Aspidochirotida) in Pagasitikos Gulf, western Aegean Sea. Greece. Turkish Journal of Zoology, 38: 306-315. https://doi.org/10.3906/zoo-1302-31

Kohler S., Gaudron S.M. \& Conand C., 2009. Reproductive biology of Actinopyga echinites and other sea cucumbers from La Reunion (Western Indian Ocean): Implications for fishery management. Western Indian Ocean Journal of Marine Science, 8: 97-111. https://doi.org/10.4314/wiojms.v8i1.56679

Koukouras A., Sinis A.I., Bobori D., Kazantzidis S. \& Kitsos M.S., 2007. The echinoderm (Deuterostomia) fauna of the Aegean Sea and comparison with those of the neighbouring seas. Journal of Biological Research Thessaloniki, 7: 67-92.

Massin C., 1982. Food and feeding mechanisms: Holothuroidea. In: Jangoux M. \& Lawrence J.M. (Eds.), Echinoderm nutrition. A.A. Balkema: Rotterdam, 15, pp. 43-55.

Massin C. \& Jangoux M., 1976. Observations écologiques sur Holothuria tubulosa. H. poli et Holothuria forskali (Echinodermata Holothuroidea) et comportament alimentaire de H. tubulosa. Cahiers de Biologis Marine, 17: 45-59.

McEuen F. \& Chia F.S., 1991. Development and metamorphosis of two psolid sea cucumbers. Psolus chitonoides and Psolidium bullatum with a review of reproductive patterns in the family Psolidae (Holothuroidea: Echinodermata). Marine Biology, 109: 267-279. https://doi.org/10.1007/bf01319395

McPherson B., 1965. Contributions to the biology of the sea urchin Tripneustes ventricosus. Bulletin of Marine Science, 15: 228-244.

Mezali K., 2008. Phylogénie, systématique, dynamique des populations et nutrition de quelques espèces d'holothuries aspidochirotes (Holothuroidea: Echinodermata) inféodées aux herbiers de posidonies de la côte Algéroise. Thèse de Doctorat d'état, Alger, Algérie: USTHB, 208 pp.

Mezali K., Soualili D.L., Neghli L. \& Conand C., 2014. Reproductive cycle of the sea cucumber Holothuria (Platyperona) sanctori (Holothuroidea: Echinodermata) in the southwestern Mediterranean Sea: interpopulation variability. Invertebrate Reproduction \& 
Development, 58: 179-189. https://doi.org/10.1080/ 07924259.2014.883337

Mezali K., Zupo V. \& Francour P., 2006. Population dynamics of Holothuria (Holothuria) tubulosa and Holothuria (Lessonothuria) polii of an Algerian Posidonia oceanica meadow. Biologia Marina Mediterranea, 13: 158-61.

Moosleitner H., 2006. Observation of natural spawning of Holothuria tubulosa. La bêche-de-mer, Bulletin d'information de la CPS, 24: 53.

Moriarty D., 1982. Feeding of Holothuria atra and Stichopus chloronotus on bacteria organic carbon and organic nitrogen in sediments of the Great Barrier Reef. Marine and Freshwater Research, 33: 255-263. https://doi.org/10.1071/mf9820255

Muthiga N., Kawaka J. \& Ndirangu S., 2009. The timing and reproductive output of the commercial sea cucumber Holothuria scabra on the Kenyan coast Estuarine. Coastal and Shelf Science, 84: 353-360. https://doi.org/10.1016/j.ecss.2009.04.011

Navarro P.G., García-Sanz S. \& Tuya F., 2012. Reproductive biology of the sea cucumber Holothuria sanctori (Echinodermata: Holothuroidea). Scientia Marina, 76: 741-752. https://doi.org/10.3989/scimar. $03543.15 b$

Nédélec H., 1982. Éthologie alimentaire de Paracentrotus lividus dans la baie de Galeria (Corse) et son impact sur les peuplements phytobenthiques. Thèse Doctorat, P.M. Curie \& Aix-Marseille II Universities, 175 pp.

Ocaña A. \& Tocino L.S., 2005. La freza de Holothuria tubulosa (Holothurioidea. Echinodermata) en el Mar de Alborán (Mar Mediterráneo). Zoologica baetica, 16: $147-150$.

Pearse J., 1968. Patterns of reproductive periodicities in four species of Indo-Pacific echinoderms. Proceedings of the Indian Academy of Sciences-Section B. Springer, pp. 247-279.

Pearse J.S. \& Cameron R.A., 1991. Echinodermata: Echinoidea. In: Reproduction of marine invertebrates. Vol. 6: Echinoderms and lophophorates. Boxwood Press, Pacific Grove, CA, pp. 513-662.

Pedrotti E., 1993. Etude des organogènese in vitro à part de racines de felhies et embryons zygotiques de merisier (Prunus avium L.). Dissertação (Doutorado em Fisiologia Vegetal)-Université d'Orléans. Orléans. France.

Pérez-Ruzafa A., 1984. Estudio sistemático. ecológico y biogeográfico de la Clase Holothuroidea en las Islas Canarias. PhD dissertation. Universidad de La Laguna. Tenerife.

Ramofafia C., Foyle T.P. \& Bell J.D., 1997. Growth of juvenile Actinopyga mauritiana (Holothuroidea) in captivity. Aquaculture, 152: 119-128. https://doi.org/ 10.1016/s0044-8486(96)01525-6
Ramofafia C., Battaglene S. \& Byrne M., 2001. Reproductive biology of Actinopyga mauritiana (Echinodermata: Holothuridae) in the Solomon Islands. Journal of the Marine Biological Association of the United Kingdom, 81: 523-531. https://doi.org/10. 1017/s0025315401004179

Rasolofonirina R., Vaitilingon D., Eeckhaut I. \& Jangoux M., 2005. Reproductive Cycle of Edible Echinoderms from the Southwestern Indian Ocean II. The Sandfish Holothuria scabra (Jaëger, 1833). Western Indian Ocean Journal of Marine Science, 4: 61-76. https://doi.org/10.4314/wiojms.v4i1.28474

Roberts D., Gebruk A., Levin V. \& Manship B., 2003. Feeding and digestive strategies in deposit-feeding holothurians. Oceanography and Marine Biology, 38: 257-262.

Schillaci D., Cusimano M.G., Cunsolo V., Saletti R., Russo D., Vazzana M., Vitale M. \& Arizza V., 2013. Immune mediators of sea-cucumber Holothuria tubulosa (Echinodermata) as source of novel antimicrobial and anti-staphylococcal biofilm agents. AMB Express, 3: 35. https://doi.org/10.4314/wiojms.v4i1. 28474

Shiell G.R. \& Uthicke S., 2006. Reproduction of the commercial sea cucumber Holothuria whitmaei (Holothuroidea: Aspidochirotida) in the Indian and Pacific Ocean regions of Australia. Marine Biology, 148: 973-986. https://doi.org/10.1007/s00227-0050113-3

Shpigel M., McBride S.C., Marciano S. \& Lupatsch I., 2004. The effect of photoperiod and temperature on the reproduction of European sea urchin Paracentrotus lividus. Aquaculture, 232: 343-355. https://doi. org/10.1016/s0044-8486(03)00539-8

Smiley S., McEuen F.S., Chaffee C. \& Krishnan S., 1991. Echinodermata: Holothuroidea. In: Giese A.C., Pearse J.S. \& Pearse V.B. (Eds.), Reproduction of Marine Invertebrates, Volume VI, Echinoderms and Lophophorates. The Boxwood Press, Pacific Grove, California, pp. 663-760.

Smith R.H., 1971. Reproductive biology of a brooding sea-star Leptasterias pusilla (Fisher) in the Monterey Bay region. Ph. D. thesis. Stanford University, California, $225 \mathrm{pp}$.

Soualili D.L., 2008. Les populations naturelles d'oursins: un outil évaluateur de l'état de santé de la d'Alger. Thèse Doctorat Océan. Univ. U.S.T.H.B., 147 pp.

Spirlet C., Grosjean P. \& Jangoux M., 1998. Reproductive cycle of the echinoid Paracentrotus lividus: analysis by means of the maturity index. Invertebrate Reproduction \& Development, 34: 69-81. https://doi. org/10.1080/07924259.1998.9652355

Spirlet C., Grosjean P. \& Jangoux M., 2000. Optimization of gonad growth by manipulation of temperature and photoperiod in cultivated sea urchins Paracen- 
trotus lividus (Lamarck) (Echinodermata). Aquaculture, 185: 85-99. https://doi.org/10.1016/s0044-8486 (99)00340-3

Starr M., Himmelman J.H. \& Therriault J.C., 1993. Environmental control of green sea urchin Strongylocentrotus droebachiensis spawning in the St. Lawrence Estuary. Canadian Journal of Fisheries and Aquatic Sciences, 50: 894-901. https://doi.org/10. 1139/f93-103

Tanaka Y., 1958. Seasonal changes occurring in the gonad of Stichopus japonicus. Bulletin of the Faculty of Fisheries, Hokkaido University, 9: 29-36.

Tuwo A. \& Conand C., 1992. Reproductive biology of the holothurian Holothuria forskali (Echinodermata). Journal of the Marine Biological Association of the United Kingdom, 72: 745-758.

Uthicke S., 1999. Sediment bioturbation and impact of feeding activity of Holothuria (Halodeima) atra and Stichopus chloronotus, two sediment feeding holothurians at Lizard Island, Great Barrier Reef. Bulletin of Marine Science, 64: 129-141.

Valls A., 2004. Natural spawning observation of Holothuria tubulosa. La bêche-de-mer, Bulletin d'information de la CPS, 19: 42.

Verlaque M. \& Nedelec H., 1983a. Biologie de Paracentrotus lividus (Lamarck) sur substrat rocheux en Corse (Méditerranée, France): alimentation des adultes. Vie et Milieu, 33: 191-201.

Verlaque M. \& Nedelec H., 1983b. Note preliminaire sur les relations biotiques Paracentrotus lividus (Lmk.) et herbier de posidonies. Rapports et procés-verbaux des réunions Commission internationale pour l'exploration scientifique de la Mer Méditerranée, 28: 157-158. 